\title{
PENGENDALIAN SERANGAN HAMA LALAT BUAH PADA INTENSITAS KERUSAKAN BUAH CABAI RAWIT (Capsicum frutescens L) DENGAN BAHAN PETROGENOL
}

\author{
Ni Komang Budiyani ${ }^{1)}$, I Wayan Sukasana ${ }^{1)}$ \\ E-mail: komang.budiyani17@gmail.com \\ 1) Dosen pada Program Studi Agroteknologi, Fakultas Sains dan Teknologi, \\ Universitas Tabanan. Jln. Wagimin No. 8 Kediri, Tabanan, Bali
}

\begin{abstract}
Control of fruit flies peststowards the damageintensity of cayenne pepper (Capsicum Frutescens L) with petrogenol substance. Cayenne pepper is a horticulture plant (vegetable) where the fruit is used for various food purposes. The decrease of the chilly yields productivity caused by several factors including the use of varieties with low yields and the attack of Plant Pests. Pests that often attack chili plants are fruit flies. Petrogenol could be used to control this pest. The attraction of fruit fly towards color can also be used in trapping fruit flies. The active ingredient of petrogenol is methyl eugenol. Methyl eugenol is an insect pheromone compound to attract the opposite sex for marriage, colonizing and eating. The method used was a randomized block design with 7 treatments and 3 replications by comparing the dose of petrogenol and the influence of petrogenol in controlling the fruit fly pests. The results showed that the 1cc of petrogenol (D3) treatment showed the best parameters in the dose usage of petrogenol in controlling fruit fly pests. The highest number of the fruit fly catches was found in $1.75 \mathrm{cc}$ dose of petrogenol (D5) which was able to reduce the damage intensity of the chili in the parameters of healthy fruit, damaged fruit, insect catches, and damage intensity. Petrogenol is able to influence the control of fruit fly pests on chili plants by observing the dose of petrogenol used for the maximum results.
\end{abstract}

Keywords : Fruit flies, Cayenne pepper, petrogenol.

\section{PENDAHULUAN}

Kebutuhan masyarakat terhadap sayuran dan buah-buahan semakin meningkat. Hal ini bukan hanya karena meningkatnya jumah penduduk, namun juga oleh meningkatnya pengetahuan masyarakat tentang pentingnya gizi yang terkandung dalam sayur dan buah.
Sayuran dan buah-buahan termasuk tanaman hortikultura yang mengandung nilai gizi yang tinggi dan merupakan sumber mineral dan vitamin yang sangat dibutuhkan oleh tubuh manusia.

Cabai rawit (Capsicum frutescens

L.) merupakan salah satu sayuran penting di dunia dan salah satu 
Budiyani : Pengendalian serangan hama lalat buah pada intensitas kerusakan buah cabe rawit

komoditas unggulan hortikultura di Indonesia. Tanaman cabai ditanam di seluruh provinsi di Indonesia dan mendapat prioritas untuk dikembangkan karena memiliki nilai ekonomi yang sangat potensial. Cabai yang dibudidayakan secara luas di Indonesia adalah cabai besar dan cabai rawit dimana kedua spesies cabai ini memiliki nilai ekonomi yang tinggi (Sulandari, 2004).

Indonesia pernah tercatat sebagai salah satu negara pengekspor cabai kering. Produksi nasional cabai pada tahun 2009 sebesar 1.378.727 ton , tahun 2010 sebesar 1.328 .864 ton, dan tahun 2011 sebesar 1.440.214 ton (BPS RI, 2011). Produksi cabai rawit Indonesia pada tahun 2011 sebesar 583.023 ton, sedangkan cabai besar sebesar 857.191 ton. (Badan Pusat Statistik dan Direktorat Jenderal Hortikultura, 2011). Produktivitas penurunan hasil cabai disebabkan beberapa faktor diantaranya penggunaan varietas dengan daya hasil rendah dan serangan Organisme Pengganggu Tanaman (OPT). Hama yang sering menyerang tanaman cabai adalah lalat buah. Lalat buah merupakan yang menyerang buah-buahan musiman, akan mempunyai dinamika populasi yang erat hubungannya dengan keberadaan buah. Lalat buah yang menyerang tanaman sayuran mempunyai dinamika populasi yang berbeda karena keberadaan inang tanaman sayuran ada sepanjang tahun. Tingkat kematangan buah berpengaruh terhadap kehidupan lalat buah.

Buah yang lebih matang lebih disukai oleh lalat buah untuk meletakkan telur daripada buah yang masih hijau. Tingkat kematangan buah sangat mempengaruhi populasi lalat buah. Jenis pakan yang banyak mengandung asam amino, vitamin, mineral, air, dan karbohidrat dapat memperpanjang umur serta meningkatkan keperidian lalat buah. Peletakan telur dipengaruhi oleh bentuk, warna, dan tekstur buah.Bagian buah yang ternaungi dan agak lunak merupakan tempat ideal untuk peletakan telur (Siwi, 2006). Menurut Vijaysegaran dan Drew (2006), Larva terdiri atas 3 instar. Larva hidup dan berkembang di dalam daging buah selama 6-9 hari. Pada instar ke tiga menjelang pupa, larva akan keluar dari dalam buah melalui lubang kecil. Setelah berada di permukaan kulit buah, larva akan melentingkan tubuh, menjatuhkan diri dan masuk ke dalam tanah. Di dalam tanah larva menjadi pupa (Djatmiadi \& Djatnika, 2001). Pupa pada awalnya 
berwarna putih, kemudian berubah menjadi kekuningan dan akhirnya menjadi coklat kemerahan.Masa pupa berkisar antara 4 - 10 hari. Pupa berada di dalam tanah atau pasir pada kedalaman 2-3 cm di bawah permukaan tanah atau pasir. Setelah 6 -13 hari, pupa menjadi imago (Djatmiadi \& Djatnika, 2001). Siklus hidup lalat buah dari telur sampai imago di daerah tropis berlangsung lebih kurang 27 hari. Lama hidup imago betina berkisar antara 23-27 hari dan imago jantan antara 13-15 hari. Imago betina setelah kopulasi akan meletakkan telur setelah 3-8 hari. Nisbah kelamin jantan berbanding dengan betina yakni 1:1 (Sodiq 1993 dalam Siwi, 2004).

Usaha pengendalian lalat buah sudah banyak dilakukan diantaranya menggunakan cara mekanik, kultur teknik, dan hayati. Namun usaha tersebut belum memberikan hasil yang menggembirakan karena terdapat banyak kendala diantaranya : serangan lalat buah banyak yang belum disadari, belum tersedia cara pengendalian yang tepat, serta pengendalian yang dilakukan tidak ekonomis. Selain itu juga dengan menggunakan pestisida kimia, namun disamping harganya cukup mahal juga banyak mencemari lingkungan, terlebih lagi bila penggunaanya tidak sesuai anjuran. Salah satu usaha pengendalian yang aman bagi lingkungan dan cukup efektif dalam menekan populasi lalat buah adalah penggunaan metil eugenol yang digunakan mengandung Petrogenol $800 \mathrm{~g} / \mathrm{l}$ sebagai atraktan nabati lalat buah. Menurut Kardinan (2003) Petrogenol adalah atraktan yang berbentuk larutan berwarna kuning jernih untuk mengendalikan lalat buah. Bahan aktif dari petrogenol adalah metil eugenol. Metil eugenol merupakan senyawa feromon serangga guna menarik lawan jenisnya untuk perkawinan, berkoloni dan untuk makan (Klawden, 2002 dalam Setiawan, 2011). Di dalam tubuh lalat buah jantan, metil eugenol diproses menjadi zat pemikat yang akan berguna dalam proses perkawinan. Dalam proses perkawinan tersebut, lalat buah betina akan memilih lalat buah jantan yang telah mengkonsumsi metil eugenol karena lalat buah jantan tersebut mampu mengeluarkan aroma yang berfungsi sebagai feromon seks (daya pikat seksual). Feromon seks dapat dipakai untuk menangkap salah satu jenis kelamin serangga atau untuk mengacaukan sistem komunikasi dalam 
Budiyani : Pengendalian serangan hama lalat buah pada intensitas kerusakan buah cabe rawit

perkawinan sehingga banyak telur yang tidak dibuahi (steril).

\section{BAHAN DAN METODE}

\section{Waktu dan Tempat penelitian}

Penelitian ini dilaksanakan pada

Bulan Mei sampai Agustus 2019 bertempat di Subak Guming, Desa Penarungan, Kecamatan Mengwi Kabupaten Badung.

\section{Alat dan Bahan Penelitian}

Alat yang digunakan pada penelitian ini adalah cangkul, dan pisau. Bahan yang digunakan adalah benih cabai rawit, pupuk, petrogenol, dolomit, botol plastik, tali rapia, kawat, bambu dan kapas.

\section{Rancangan Percobaan}

Penelitian ini menggunakan Rancangan Acak Kelompok (RAK) dengan perlakuan menggunakan petrogenol yang terdiri atas tujuh level dosis yang diulang masing-masing sebanyak tiga kali. Pengujian tingkat level dosis perangkap petrogenol yang digunakan untuk mengendalikan lalat buah disajikan pada tabel 1 .

Tabel.1 Perlakuan Dosis petrogenol dalam mengendikan lalat buah

\begin{tabular}{lll}
\hline No & Kode Perlakuan & Jumlah dosis \\
\hline 1. & D1 & $0,50 \mathrm{cc}$ petrogenol \\
2. & D2 & $0,75 \mathrm{cc}$ petrogenol \\
3. & D3 & $1 \mathrm{cc}$ cc petrogenol \\
4. & D4 & $1,50 \mathrm{cc}$ petrogenol \\
5. & D5 & $1,75 \mathrm{cc}$ petrogenol \\
6. & D6 & 2,0 cc petrogenol \\
7. & Kontrol & air streril tanpa perlakuan petrogenol \\
\hline
\end{tabular}

\section{Parameter pengamatan}

Pemasangan

perangkap

petrogenol dilaksanakan pada saat buah tanaman cabai menjelang masak. Setiap petak cabai rawit dipasang satu perangkap petrogenol dengan jarak antar perangkap $9 \mathrm{~m} \times 10 \mathrm{~m}$ yang digantung dengan menggunakan tali raffia pada ajir yang terbuat dari bambu dengan posisi vertikal setinggi kanopi cabai.Perangkap dibuat dari botol plastik volume 1.500 ml dengan 4 lubang masuk pada setiap botol. Pada bagian tengah botol diikatkan segumpal kapas yang ditetesi petragonol. Intensitas kerusakan buah cabai, parameter yang diamati adalah: jumlah buah sehat, jumlah lalat buah 
yang tertangkap, jumlah buah rusak, intensitas kerusakan.

\section{Jumlah buah sehat}

Penghitungan buah sehat tanaman cabai dilakukan dengan menghitung buah sehat yang memiliki kriteria dan nampak sehat dan diamati saat 2 minggu sebelum panen.

\section{Jumlah tangkapan lalat buah}

Jumlah lalat buah yang tertangkap dilakukan dengan pengamatan setiap pagi hari setelah pemasangan perangkap sehingga tidak ada lalat buah dalam perangkap.

\section{Jumlah buah rusak}

Penghitungan buah rusak tanaman cabai dilakukan dengan menghitung jumlah bauh rusak yang memiliki kriteria dan nampak mengalami rusak buah dan diamati saat 2 minggu sebelum panen.

\section{Intensitas kerusakan}

Intensitas Kerusakan buah cabai dilakukan pada waktu panen dengan menggunakan rumus :

$$
I=\frac{a}{b}
$$

Dimana:

I $=$ Intensitas kerusakan (\%)

a = buah cabai yang terserang

$\mathrm{b}=$ total buah yang diamati

\section{Analisis Data}

Pengamatan terhadap parameter yang diamati dilakukan tiap hari, data analisis dengan menggunakan varian (anova), jika berbeda nyata kemudian data diuji dengan uji kisaran berganda Duncan pada taraf $5 \%$.

\section{HASIL DAN PEMBAHASAN}

Hasil penelitian berdasarkan analisis statistik menunjukkan bahwa pengaruh dosis petrogenol terhadap jumlah buah sehat, jumlah tangkapan lalat buah, jumlah buah rusakdan intensitas kerusakan buah cabai menujukkan berpengaruh yang sangat nyata, terlihat pada tabel 2 .

Tabel 2. Signifikansi pengaruh dosis petrogenol terhadap beberapa variabel pengamatan

\begin{tabular}{rll}
\hline No & Variabel pengamatan & N-Signifikansi \\
\hline 1. & Jumlah Buah sehat & $* *$ \\
2. & Jumlah Tangkapan lalat buah & $* *$ \\
3. & Jumlah buah busuk & $* *$ \\
4. & Intensitas kerusakan & $* *$ \\
\hline
\end{tabular}

Keterangan $:^{* *}$ berpengaruh sangat nyata $(\mathrm{p} \leq 0,01)$ 
Budiyani : Pengendalian serangan hama lalat buah pada intensitas kerusakan buah cabe rawit

Kemampuan dosis petrogenol dalam penelitian ini terhadap ketahanan buah sehat tanaman cabai, jumlah tangkapan lalat buah dan jumlah buah busuk merupakan hasil yang baik untuk mengatasi serangan lalat buah khususnya terhadap tanaman cabai. Hal ini dapat dilihat pada hasil pengamatan pada Tabel 3.

Pemberian perlakuan Petrogenol menunjukkan pengaruh yangberbeda nyata $(\mathrm{P}<0,05)$ mendapatkan hasil yang lebih tinggi jumlah buah sehat dibandingkan dengan tanpa petrogenol (kontrol) (Tabel 3). Pada tingkat dosis Petrogenol antara D1, D2, D3, D4, D5 dan D6 yang diberikan sebagai perlakuan, menunjukkan jumlah buah sehat yang berbeda tidak nyata $(\mathrm{P} \geq$ $0,05)$ dengan rata-rata jumlah buah sehat adalah sebanyak 111,67 buah. Hal ini menunjukkan Petrogenol yang berikan pada tanaman cabai cukup efektif dalam pengendalian hama lalat buah. Menurut Kardinan (2003) petrogenol adalah atraktan yang berbentuk larutan berwarna kuning jernih untuk mengendalikan lalat buah. Bahan aktif dari petrogenol adalah metil eugenol. Metil eugenol merupakan senyawa feromon serangga guna menarik lawan jenisnya untuk perkawinan, berkoloni dan untuk makan. Didalam tubuh lalat buah jantan metil eugenol diproses menjadi zat pemikat yang akan berguna dalam proses perkawinan. Dalam proses perkawinan tersebut, lalat buah betina akan memilih lalat buah jantan yang telah mengkonsumsi metil eugenol karena lalat buah jantan tersebut mampu mengeluarkan aroma yang berfungsi sebagai feromon seks (daya pikat seksual) dan akan membantu dalam penangkapan lalat buah. Sehingga makin banyak lalat buah yang tertangkap pada perangkap dapat menghindari adanya serangan lalat buah pada cabai dan tidak membuat cabai mati atau rusak. Sehingga pengaruh perlakuan dari dosis petrogenol yang tinggi mampu mengendalikan lalat buah dan terperangkap. 
Tabel 3. Pengaruh Dosis Petrogenol terhadap parameter Jumlah Buah sehat, Jumlah Tangkapan Lalat Buah, Jumlah Buah Rusak dan Intensitas Kerusakan

\begin{tabular}{llcccl}
\hline No & Perlakuan & $\begin{array}{c}\text { Jumlah Buah } \\
\text { Sehat (buah) }\end{array}$ & $\begin{array}{l}\text { Tangkapan lalat buah } \\
\text { (ekor) }\end{array}$ & $\begin{array}{l}\text { Jumlah Buah } \\
\text { rusak(buah) }\end{array}$ & $\begin{array}{l}\text { Intensitas } \\
\text { kerusakan } \\
(\%)\end{array}$ \\
\hline 1 & D1 & $108 \mathrm{a}$ & $8 \mathrm{c}$ & $16,0 \mathrm{a}$ & $24,0 \mathrm{a}$ \\
2 & D2 & $111 \mathrm{a}$ & $8 \mathrm{bc}$ & $6,6 \mathrm{~b}$ & $22,3 \mathrm{ab}$ \\
3 & D3 & $113 \mathrm{a}$ & $16 \mathrm{a}$ & $6,3 \mathrm{bc}$ & $21,0 \mathrm{~b}$ \\
4 & D4 & $111 \mathrm{a}$ & $9 \mathrm{bc}$ & $6,0 \mathrm{bc}$ & $17,2 \mathrm{c}$ \\
5 & D5 & $114 \mathrm{a}$ & $8 \mathrm{c}$ & $6,6 \mathrm{~b}$ & $15,6 \mathrm{~cd}$ \\
6 & D6 & $113 \mathrm{a}$ & $9 \mathrm{bc}$ & $4,0 \mathrm{c}$ & $13,4 \mathrm{~d}$ \\
7 & Kontrol & $83 \mathrm{~b}$ & $7 \mathrm{~d}$ & $16,0 \mathrm{a}$ & $24,5 \mathrm{a}$ \\
\hline
\end{tabular}

Keterangan : Angka-angka yang diikuti oleh huruf yang sama pada kolom yang sama menunjukkan berbeda tidak nyata pada uji Duncant taraf $5 \%$.

Pemberian perlakuan Petrogenol terhadap jumlah tangkapan lalat buah menunjukkan jumlah yang nyata $(\mathrm{P}<0,05)$ tertinggi pada perlakuan D3 yaitu sebanyak 16 ekor dari pada perlakuan dosis petrogenol yang lainnya (Tabel 3), sedangkan Jumlah tangkapan lalat buah terendah secara nyata $(\mathrm{P}<0,05)$ didapatkan pada perlakuan tanpa petrogenol (kontrol). Terbukti Petrogenol dengan kandungan Metil Eugenol yang digunakan mengandung Petrogenol 800 g/l merupakan senyawa pemikat serangga terutama lalat buah, sehingga jumlah lalat buah yang dapat ditangkap lebih banyak. Metil eugenol bersifat mudah menguap dan melepaskan aroma wangi. Susunan Metil eugenol terdiri dari unsur $\mathrm{C}, \mathrm{H}$ dan $\mathrm{O}$ $\left(\mathrm{C}_{12} \mathrm{H}_{24} \mathrm{O}_{2}\right)$. Zat ini merupan food lure atau dibutuhkan oleh lalat buah jantan untuk dikonsumsi (Iwahashi et al., 1996). Metil eugenol telah dilaporkan efektif untuk mengendalikan hama lalat buah pada tanaman cabai. Menurut Fatimah (2001) aplikasi metil eugenol bahan petrogenol dengan dosis 1,1 ml/perangkap memberikan pengaruh yang optimum terhadap hasil jumlah tangkapan lalat buah pada tanaman cabai.

Ciri-ciri fisiologi buah cabai merah seperti aroma, kandungan, ukuran, warna dan bentuk buah cabi merah juga dapat mempengaruhi intensitas serangan lalat buah. Menurut 
Budiyani : Pengendalian serangan hama lalat buah pada intensitas kerusakan buah cabe rawit

Chapman (1969) serangga akan tumbuh dan berkembang dengan normal apabila mendapatkan pakan dalam jumlah yang cukup dan baik kualitasnya. Kualitas pakan banyak ditentukan oleh mutu gizi pakan tersebut, sedangkan mutu gizi pakan ditentukan oleh nutrisi yang terkandung didalamnya. Atkins (1980) menambahkan bahwa pemilihan pakan oleh serangga tergantung pada kandungan nutrisi. Rangsangan makan timbul karna adanya zat perangsang makan seperti gula, lipida dan asam amino.

Mengikat lalat buah terhadap warna juga dapat dimanfaatkan dalam merangkap lalat buah, karena imago lalat buah betina agan terbang disekitar tajuk sebelum meletakan telurnya. Kriteria kematangan buah ikut menentukan prilaku lalat buah dalam menentukan tanaman inangnya (Sunarno. 2011). Perlakuan dosis metil eugenol berpengaruh terhadap keefektifan pengendalian lalat buah, sehingga perlakuan dosis petrogenol memberikan pengaruh ketertarikan lalat buah untuk masuk dalam perangkap. Semakin tinggi dosis yang digunakan maka semakin banyak tangkapan lalat buah yang akan masuk dalam perangkap untuk mengendalikan lalat buah. Metil eugenol yang digunakan mengandung Petrogenol yang merupakan senyawa pemikat serangga terutama lalat buah. Zat ini bersifat mudah menguap dan melepaskan aroma wangi.Metil eugenol dapat diperoleh di pasaran dengan harga terjangkau dan pemakaiannya cukup mudah (Patty, 2012).

Pada parameter jumlah buah yang rusak, didapatkan jumlah buah yang rusak tertinggi pada perlakuan D1 dan tanpa petrogenol (control) yang menunjukkan perbedaan yang tidak nyata $(\mathrm{P} \geq 0,05)$ yaitu masing-masing sejumlah 16 buah (Tabel 3). Perlakuan petrogenol terhadap jumlah buah yang rusak, terendah didapatkan pada perlakuan D6 yaitu sebanyak 4 buah yang berbeda tidak nyata $(P \geq 0,05)$ dengan perlakuan D3 (1cc) dan D4 (1,50 cc). Pengaruh pemberian dosis petrogenol menunjukkan pengaruh nyata terhadap jumlah buah rusak tanaman cabai yang semakin kecil, karena jumlah tangkapan lalat buah yang semakin banyak. Pernyataan ini didukung oleh penelitian Patty (2012) yang menyatakan bahwa efektif untuk menangkap lalat buah terdapat pada perlakuan $\mathrm{C}(1,5 \mathrm{ml})$ jumlah tangkapan.

Lalat buah menyerang tanaman cabai hal ini disebabkan oleh morfologi 
lalat buah yang sudah terperangkap Telur kemudian menetas menjadi larva yang hidup, makan dan berkembang di dalam buah sehingga buah menjadi busuk berisi larva atau dikenal dengan belatung. Setelah telur menetas, larva membuat lubang didalam buah sehingga mempermudah masuknya bakteri dan cendawan. Lalat buah hidup secara simbiosis mutualisme dengan bakteri, sehingga ketika lalat buah meletakkan telur pada buah, bakteri akan terbawa dengan diikuti cendawan yang akhirnya menyebabkan busuk.

Sesudah telur menetas, larva mengorek daging buah sambil mengeluarkan enzim perusak atau pencerna yang berfungsi melunakkan daging buah sehingga mudah diisap dan dicerna. Enzim tersebut diketahui yang mempercepat pembusukan, selain bakteri pembusuk yang mempercepat aktivitas pembusukan buah. Bakteri tersebut hidup pada dinding ovari, tembolok, dan ileum lalat (Kardinan, A. 2003).Buah yang terserang lalat buah dan busuk, akhirnya jatuh ke tanah. Serangan lalat buah pada buah yang terserang terdapat luka tusukan dalam ukuran kecil, seperti tertusuk jarum. Hal tersebut akan mengakibatkan terdapatnya spot hitam pada buah. Buah yang terserang menjadi busuk lunak dan menghitam. Luka akibat tusukan menimbulkan infeksi sekunder berupa busuk buah, baik yang disebabkan oleh cendawan maupun bakteri. Buah yang terkena tusukan lalat buah ini akan rontok. Jika buah dibelah akan terlihat biji-biji berwarna hitam dan terdapat belatung yang merupakan larva lalat buah.Lalat buah merupakan jenis serangga yang aktif pada pagi hari dan sore hari. Aktivitas lalat buah dipengaruhi oleh banyak faktor diantaranya adalah faktor suhu, kelembaban, cahaya dan ketersediaan inang. Lalat buah dewasa akan aktif terbang pada jam 06.00 - 09.00 pagi atau sore hari jam 15.00 - 18.00 (Hasyim at al., 2014).

Ketertarikan lalat buah terhadap warna juga dapat dimanfaatkan dalam merangkap lalat buah, karena imago lalat buah betina akan terbang disekitar tajuk sebelum meletakan telurnya. Kriteria kematangan buah ikut menentukan prilaku lalat buah dalam menentukan tanaman inangnya. Perlakuan dosis metil eugenol berpengaruh terhadap keefektifan pengendalian lalat buah, sehingga perlakuan dosis petrogenol memberikan pengaruh ketertarikan lalat buah untuk masuk dalam perangkap. 
Budiyani : Pengendalian serangan hama lalat buah pada intensitas kerusakan buah cabe rawit

Menurut Flecher (1997), lalat buah dewasa seringkali tertarik terhadap senyawa aromatik yang terdapat pada bagian buah cabai yang sudah masak, beberapa senyawa kimia yang berhasil disintesa dari buah-buahan.

Pemberian perlakuan petrogenol pada tanaman cabai menunjukkan intensitas kerusakan buah cabai tertinggi pada perlakuan tanpa petrogenol (Kontrol) yang berbeda tidak nyata $(\mathrm{P} \geq 0,05)$ dengan perlakuan D1. Rata-rata intensitas kerusakan buah pada perlakuan control dan perlakuan D1 masing-masing secara berurutan $24,5 \%$ dan 24,0\% (Tabel 3). Sedangkan intensitas kerusakan buah terendah didapat pada perlakuan D6 yang berbeda tidak nyata $(P \geq 0,05)$ dengan perlakuan D5 yaitu masing-masing secara berurutan $13,4 \%$ dan $15,6 \%$. Hal ini menunjukkan meningkatnya dosis petrogenol yang diberikan pada tanaman cabai dapat menurunkan intensitas kerusakan buah cabai. Dengan penggunaan petrogenol dengan dosis lebih tinggi menunjukkan tendensi jumlah tangkapan lalat buah yang semakin banyak sehingga dengan demikian serangan hama lalat buah menjadi berkurang. Berkurangnya serangan hama lalat buah mampu dalam meningkatkan hasil produktivitas cabai. Hal ini didukung oleh pendapat Rouse et al. (2005) yang menyatakan bahwa lalat buah merupakan salah satu hama yang sangat merugikan produksi buahbuahan dan sayuran, baik secara kuantitas maupun kualitas. Penelitian Sutjipto at al. (2011) melaporkan bahwa dosis metil eugenol yang disuling dari ekstrak daun selasih 1,25 ml/perangkap merupakan dosis yang optimal untuk mengendalikan lalat buah pada pertanaman cabai.

Tingginya hasil panen pada perlakuan sejalan dengan persentase intensitas serangan hama lalat buah pada perlakuan, semakin rendahnya intensitas serangan maka hasil produksi akan semakin meningkat dimana hasil pengamatan intensitas terendah pada perlakuan hasil panen terendah dengan rata-rata 0,83 hal tersebut sesuai dengan laju intenitas tertinggi yaitu pada perlakuan yang menggunakan bahan petrogenol, pernyataan tersebut didukung dari hasil penelitian (Hasanah, 2018).

Salah satu usaha pengendalian yang aman bagi lingkungan dan cukup efektif dalam menekan populasi lalat buah adalah penggunaan metil eugenol sebagai atraktan nabati lalat buah. Metil 
eugenol yang digunakan mengandung Petrogenol $800 \mathrm{~g} / \mathrm{l}$ merupakan senyawa pemikat serangga terutama lalat buah. Zat ini bersifat mudah menguap dan melepaskan aroma wangi. Metil eugenol dapat diperoleh di pasaran dengan harga terjangkau dan pemakaiannya cukup mudah (Nugroho, 1997).

\section{SIMPULAN}

Berdasarkan hasil kajian pengaruh dosisi petrogenol terhadap serangan lalat buah pada tanaman cabai, maka dapat disimpulkan bahwa perlakuan dengan menggunakan bahan petrogenol mampu mempengaruhi dalam menangkap serangan lalat buah. Pengaruh dosis 1cc petrogenol (D3) dapat menunjukkan perlakuan yang baik dalam mengendalikan serangan lalat buah dengan jumlah tangkapan lalat buah tertinggi terdapat pada perlakuan dosis $1,75 \mathrm{cc}$ petrogenol (D5) mampu mengurangi intensitas kerusakan buah cabai. Sehingga dapat dikatakan petrogenol mampu mempengaruhi dalam mengendalikan serangan hama lalat buah pada tanaman cabai dalam memperhatikan dosis petrogenol yang digunakan untuk hasil yang maksimal.

\section{UCAPAN TERIMAKASIH}

Pada kesempatan ini, penulis mengucapkan terimakasih yang sebesarbesarnya kepada semua pihak yang telah mendukung pelaksanaan penelitian ini baik dari pihak lembaga, lingkungan, lembaga pendidikan Universitas Tabanan. Semoga Tuhan Yang Maha Esa memberikan berkahnya kepada kita semua.

\section{DAFTAR PUSTAKA}

Atkins M. D. 1980.Introduction to Insect Behavior.Mac-Millan Publisher. London.

Badan Pusat Statistik, 2011. Produksi Cabai Nasional.

Chapman R. F. 1969. The Insects Structure And Fuction. American Elsevier publishing. Co. Inc. New York

Djatmiadi \& Djatnika 2001.Petunjuk Teknis Surveilans Lalat Buah.Pusat Teknik dan Metode Karantina Hewan dan Tumbuhan. Jakarta: Badan Karantina Pertanian

Drew D. 2011. The Australian Handbook For The Identification of Fruit Flies. Volume ke-1, Australia:Canberra.

Fatimah, S. 2001. Pengaruh Pemberian Methyl Eugenol terhadap Daya Memikat Hama Lalat Buah (Dacus dorsalis Hend.) Tanaman Cabai (Capsicum annuum L.). (Skripsi). Universitas Jember 
Budiyani : Pengendalian serangan hama lalat buah pada intensitas kerusakan buah cabe rawit

Hasanah.2018. Intensitas Serangan Hama Lalat Buah Cabai (Bactrocera Spp.)Yang Dikendalikan Dengan Beberapa Jenis Perangkap Serangga.Mataram. Jurnal Fakultas Pertanian Universitas Mataram.

Hasyim, A., Muryatia \& De Kogel, W.J. 2008. Population fluctuation of adult males of fruit fly Bactrocera tau Walker (Diptera: Tephritidae) in passion fruit orchards in relation to abiotic factors and sanitation. Indonesian Journal of Agricultural Science 9 (1): 29-33.

Iwahashi, O., S. Sastrodihardjo and T.S. Subahar. 1996. The Mysteri of Methyl Eugenol: 1. Why Methyl Eugenol is so Effective for Controlling Fruit Flies? Presented in XIX International Congress of Entomology, Firenze-Italy.

Flecher. 1997. The Biology of Dacinae Fruit Flies. Ann. Rev. Entomol. 32: $115-144$

Kardinan, A. 2003. Selasih Tanaman Keramat Multimanfaat. Jakarta: Agromedia Pustaka.

Kardinan, A. 1997.Lalat Buah dan Pengendaliannya. J Bul. Littro 7 : 44-51.

Nugroho, S. P. 1997. Hama Lalat Buah dan Pengendaliannya, Penerbit Kanisius, Yogyakarta.

Rouse P., Ryckewaert. 2005. Adjustment Of Field Cage Methodology For Testing Food Attractants For Fruit Flies (Diptera:Tephritidae) Ann. Entomol.Soc.Am. 98(3):402408
Setiawan, E. D. 2011. Pengaruh Kombinasi Petrogenol Dan Ekstrak Jeruk Tehadap Feeding Strategy Lalat Buah Bactrocera dorsalis.Skripsi. Biologi FMIPA. Padang: Universitas Negeri Padang.

Siwi SS, Hidayat P \& Suputa. 2006. Taksonomi dan Bioekologi Lalat Buah Penting di Indonesia (Diptera: Tephritidae). Bogor: Balai Besar Penelitian dan Pengembangan Bioteknologi dan Sumberdaya Genetik Pertanian

Sulandari, S. 2004. Karakterisasi biologi, serologi dan sidik jari DNA virus penyebab penyakit daun keriting kuning cabai. Institut pertanian Bogor

Sunarno. 2011. Ketertarikan Serangga Hama Lalat Buah Terhadap Berbagai Papan Perangkap

Sutjipto, Prastowo, S. \& Jadmiko, M.W. 2011.Keandalan Ekstrak Daun Selasih Sebagai Insektisida Nabati untuk Pengendalian Lalat Buah pada Cabai Merah.Laporan Penelitian Hibah Bersaing XIV/2 Perguruan Tinggi Tahun Anggaran 2007.

Sodiq, M. 1993. Aspek Biologi dan Sebaran Populasi Lalat Buah Pada Tanaman Mangga dalam Kaitan dengan Pengembangan Model Pengendalian Hama Terpadu. Disertasi, Program Pascasarjana Universitas Airlangga. 
AGRICA, Vol. 13, No. 1 (2020)

Patty, J,A. 2012. Efektivitas Metil Eugenol Terhadap Penangkapan Lalat Buah (Bactrocera Dorsalis) pada Pertanaman Cabai.Ambon.Jurnal. Agrologia, Vol.1, No. 1.
Vijaysegaran, S., R.A.I., Drew. 2006. Fruit fly spesies of Indonesia: Host range and distribution. ICMPFF: Griffith University. 